\title{
Gastronomy's influence on fruits and vegetables acceptance by overweight children
}

\begin{abstract}
The present study aimed to assess the acceptance of fruits and vegetables, prepared with gastronomy techniques, by overweight children $(n=25)$ from a public school in Rio Paranaíba city, Minas Gerais, Brazil. The consumption of orange, papaya, watermelon, zucchini, chayote and beet was observed, before and after the use of gastronomic techniques. To compare the grades, the Wilcoxon test was applied. To associate the gender, age, consumption and food acceptance was applied the Chisquare test at $5 \%$. The results showed that consumption frequency, for both fruits and vegetables, was considered low. The gastronomic techniques did not improve the acceptance $(p>0.05)$. However, the grades assigned to vegetables after gastronomy techniques application increased, highlighting its role over health eating promotion. Based on the results, was possible to affirm that the gastronomy techniques have provided higher scores for vegetables evaluated. However, complementary studies are necessary to evaluate if those techniques could be used as education strategies in order to enhance fruits and vegetables consumption by children.
\end{abstract}

Keywords: gastronomic techniques, sensory analysis, obesity
Volume 7 Issue 3 - 2017

\author{
Virgínia Souza Santos,' Maria Clara Francisco \\ Nunes,' Martha Elisa Ferreira de Almeida,' \\ Letícia Maria de Melo,' Thalita Riquelme \\ Augusto-Obara, ${ }^{2}$ Leila Aparecida Kauchakje \\ Pedrosa ${ }^{3}$ \\ 'Biological Science and Health Institute, Federal University of \\ Viçosa, Brazil \\ ${ }^{2}$ Department of Agroindustry, Food and Nutrition, University of \\ São Paulo, São Paulo, Brazil \\ ${ }^{3}$ Department of Nursing Education and Community Health \\ Nursing Course, University Federal do Triângulo Mineiro, Brazil
}

Correspondence: Virgínia Souza Santos, Federal University of Viçosa, Rio Paranaíba Campus, Highway MG-230, Km 7, Rio Paranaíba, Minas Gerais, Brazil, Zip code: 38810000 , Email virginiasantos@ufv.br

Received:September 27, 2017 | Published: October 17, 2017

\section{Introduction}

The Household Budget Survey of 2008/2009 showed a growing prevalence of overweight, reaching over $30 \%$ of children between 5 and 9years old. ${ }^{1}$ The weight excess can be resulted from the interaction between biological, behavioral and environmental factors. Inadequate eating habits besides fruits and vegetables low consumption are among the 10 risk factors for the occurrence of overweight in the whole world..$^{2,3}$ The obesity is a serious public health problem which can induce cardiovascular diseases in young adults. ${ }^{4}$ According to Food and Nutrition Surveillance System Survey, in 2008 the consumption of fruits and vegetables was considered inadequate to $30 \%$ of 26,000 surveyed children and teenagers, since this amount did not report consuming these kinds of food during the week. ${ }^{5}$ Fruits and vegetables consumption of the general population is lower than the recommended amount, which is 400 to 500 g per day. ${ }^{6}$ According to the Brazilian Institute of Geography and Statistics, the consumption of these foods is lower than the recommended to more than $90 \%$ of Brazilian citizens. ${ }^{1}$

Along the life, eating habits are development and the childhood is the most important stage to establish health habits. The relationship between an individual and the act of eating is not only developed from what you eat to satisfy the biological needs, but also by symbolic and social factors. ${ }^{2,7}$ The use of gastronomic techniques can transform the act of eating to a pleasure act, seeking people health and wellness, besides presenting suitable nutritionally preparations [8]. On gastronomy, dishes are arranged in a certainly way to make aliment visible to the consumer making all ingredients that compose the preparation perceptible. The variety and harmony between colors are very important to make food pleasing to the view as well to taste. ${ }^{9}$ This study aimed to assess the influence of gastronomy techniques on fruits and vegetables acceptance by overweight children.

\section{Materials and methods}

This is a quantitative and experimental study, previously approved by Research Ethics Committee of University of Viçosa, Brazil, protocol $\mathrm{n}$ - 473.739. The research was conducted with children, between 7 to 9years, overweight diagnosed, registered in a public school of Rio Paranaíba city, Minas Gerais State, Brazil. The nutritional diagnosis of the students was obtained through information from another study carried out by the same researchers, in the same school. Thus, 67 were overweight and were invited to participate in the study, through an invitation sent to parents or guardians. If they were in agreement with the participation, they should sign a Free and Informed Consent Term and send it back to the researchers. For the development of the research were selected 25 overweight diagnosed children.

Based on informal consultations with professionals related to the preparation of school meals, six types of food were selected in situ, considering their low acceptance by the children. The chosen fruits were orange, papaya and watermelon, and the vegetables were zucchini, chayote and beet which are important dietary components due to providing essential vitamins and minerals for the development and growth. A frequency consumption questionnaire of fruits and vegetables was applied, and subsequently was performed an acceptance sensory evaluation test through facial hedonic scale of five points (Figure 1), proposed by the Food and Nutrition Collaborating Center School.

The foods were purchased in the local market of Rio Paranaíba (MG) and presentation of the samples was standardized, according to the sensory analysis techniques. ${ }^{11}$ The preparations were developed by the pre-preparation and preparation methods, in the school kitchen, according to the hygienic-sanitary requirements established by Collegiate Board Resolution $\mathrm{n}^{\mathrm{o}}$ 216, September $15^{\text {th }}, 2004 .^{12}$ The food was served for each participant, twice, with different 
forms of presentation. First of all they were presented in their usual consumption. After 15 days, the same foods were offered, prepared with gastronomic techniques which consisted of differentiated cuts to improve the visual presentation of fruits and vegetables offered to children.

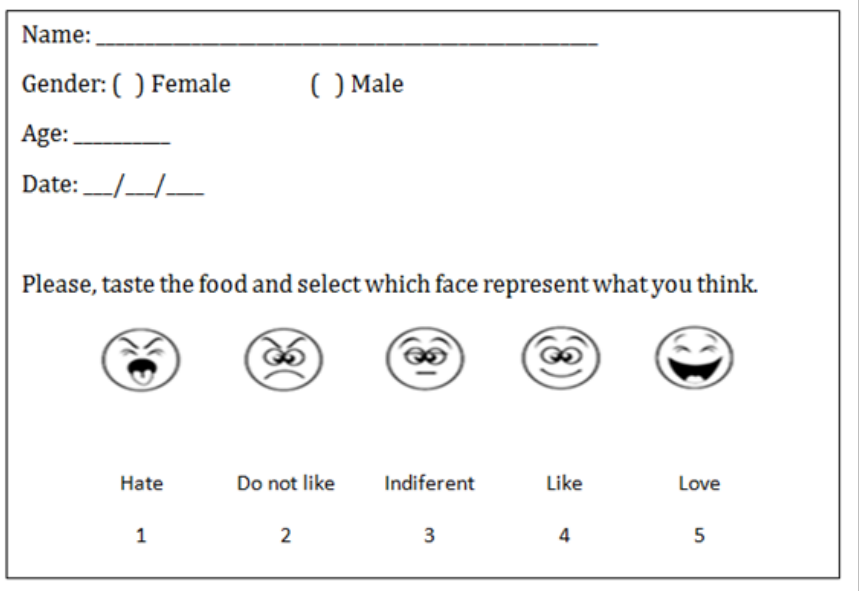

Figure I Adapted sensory analysis form of the manual of acceptance testing of application by national school feeding programme. ${ }^{10}$

The sensory analysis was performed in individual cabins, during class time, from $10 \mathrm{am}$ to $11 \mathrm{am}$ for students of the morning shift and from $15 \mathrm{pm}$ to $16 \mathrm{pm}$ for students of the afternoon shift. ${ }^{11}$ For acceptance test analysis, before and after the use of gastronomic techniques the Wilcoxon test were performed, and to associate the gender, age and consumption with food acceptance was performed the Chi-square test. Both tests were performed at the 5\% significance software through Statistical Package for the Social Sciences software (SPSS), 20.0 version.

\section{Results}

The study was realized with 25 overweight children, of which $60 \%(n=15)$ are female and $40 \%(n=10)$ male. Most of them do not have the habit of eating fruits and vegetables (Figure 2). Although the children in the study lives in a city with higher access to healthy food, this fact was not enough to include this aliments for foods in their eating habits, emphasizing the importance of developing actions to encourage fruits and vegetables consumption in that public.

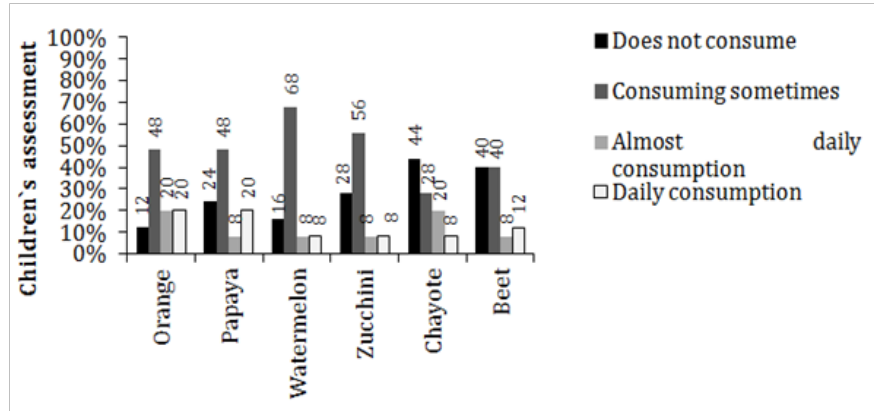

Figure 2 Food consumption frequency of fruits and vegetables by overweight children.

The grades attributed to food before and after the use of gastronomic techniques are shown on Table 1. Is not possible to verify statistical difference between any of the assessed foods ( $p>0.05)$. However, the gastronomic techniques were efficient to increase the grades conferred to vegetables in the evaluation by children.
Table I Mean and standard deviation of grades before and after gastronomic techniques used over fruits and vegetables

\begin{tabular}{lll}
\hline Food & Before & After \\
\hline Orange & $4.54 \pm 0.76^{\mathrm{ns}}$ & $4.38 \pm 0.85^{\mathrm{ns}}$ \\
Papaya & $4.88 \pm 0.33^{\mathrm{ns}}$ & $4.77 \pm 0.43^{\mathrm{ns}}$ \\
Watermelon & $4.73 \pm 0.53^{\mathrm{ns}}$ & $4.69 \pm 0.47^{\mathrm{ns}}$ \\
Zucchini & $3.00 \pm 1.72^{\mathrm{ns}}$ & $3.54 \pm 1.33^{\mathrm{ns}}$ \\
Chayote & $3.54 \pm 1.63^{\mathrm{ns}}$ & $3.62 \pm 1.63^{\mathrm{ns}}$ \\
& & \\
Beet & $3.04 \pm 1.56^{\mathrm{ns}}$ & $3.54 \pm 1.42^{\mathrm{ns}}$ \\
\hline
\end{tabular}

ns-No significative by Wilcoxon test at $5 \%$ of significance.

The scores attributed for fruits decreased after use of gastronomic techniques, suggesting that this fact is resultant by the alteration of the commonly form of the foods consumed by children. The daily vegetables consumption was lower than fruits consumption (Figure 1). There are no studies that approach directly the influence gastronomy on fruit and vegetables acceptance among children. The gender only presented an association with grades attributed to chayote after the use of gastronomic techniques (Table 2). The age showed association with the watermelon grades, before and after the use of gastronomic techniques. The food consumption also was associate with watermelon grades (before and after), zucchini grades (before) and beet (after) the use of gastronomic techniques (Figure 3) (Figure 4).

Table 2 P-values for the notes of fruits and vegetables before and after the use of gastronomic techniques, gender, age and food consumption

\begin{tabular}{|c|c|c|c|c|}
\hline Grades / Before or After & & Gender & Age & $\begin{array}{l}\text { Food } \\
\text { consumption }\end{array}$ \\
\hline & B & 0.819 & 0.723 & 0.148 \\
\hline \multicolumn{5}{|l|}{ Orange } \\
\hline & $A$ & 0.169 & 0.794 & 0.695 \\
\hline & B & 0.382 & 0.856 & 0.224 \\
\hline \multicolumn{5}{|l|}{ Papaya } \\
\hline & A & 0.382 & 0.856 & 0.224 \\
\hline & B & 0.234 & $0.019 *$ & $0.006^{*}$ \\
\hline \multicolumn{5}{|l|}{ Watermelon } \\
\hline & $A$ & 0.234 & $0.019 *$ & $0.006 *$ \\
\hline & $B$ & 0.059 & 0.41 & $0.036^{*}$ \\
\hline \multicolumn{5}{|l|}{ Zucchini } \\
\hline & A & 0.462 & 0.826 & 0.068 \\
\hline & B & 0.279 & 0.46 & 0.211 \\
\hline \multicolumn{5}{|l|}{ Chayote } \\
\hline & A & $0.008 *$ & 0.125 & 0.462 \\
\hline & B & 0.599 & 0.662 & 0.237 \\
\hline \multicolumn{5}{|l|}{ Beet } \\
\hline & $A$ & 0.059 & 0.931 & $0.014^{*}$ \\
\hline
\end{tabular}

B, before; A, after; *Significative by Chi-square test at $5 \%$ of significance. 

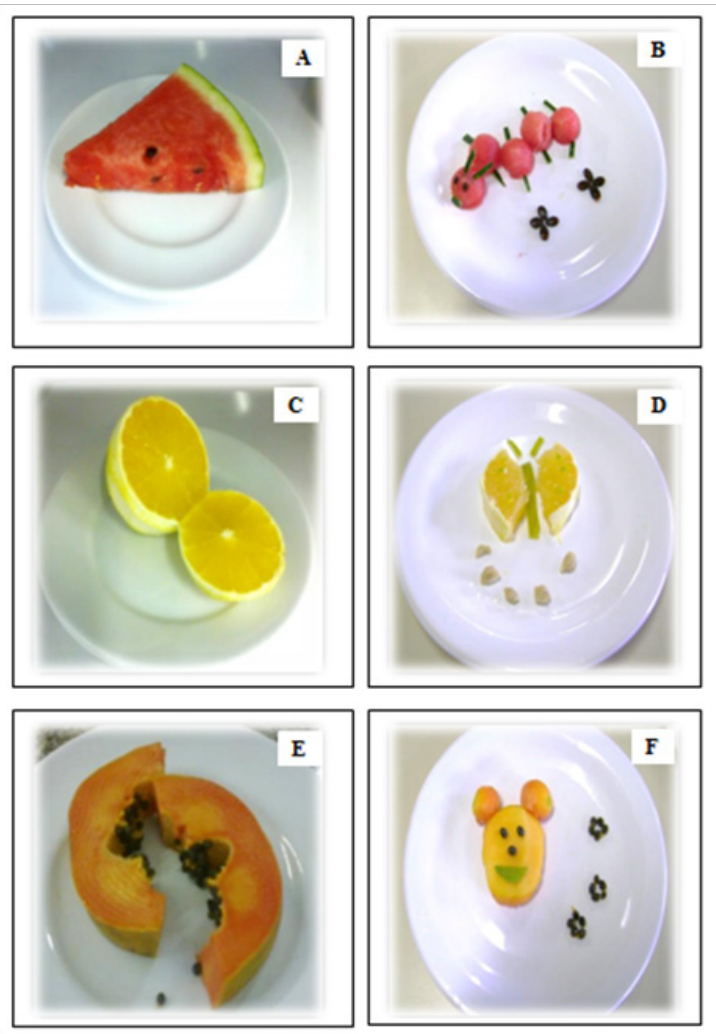

Figure 3 Use of the gastronomic techniques in fruits.A) Slice of watermelon; B) Centipede made with watermelon; C) Orange; D) Butterfly made with orange; E) Slice of papaya; F) Bear made with papaya.
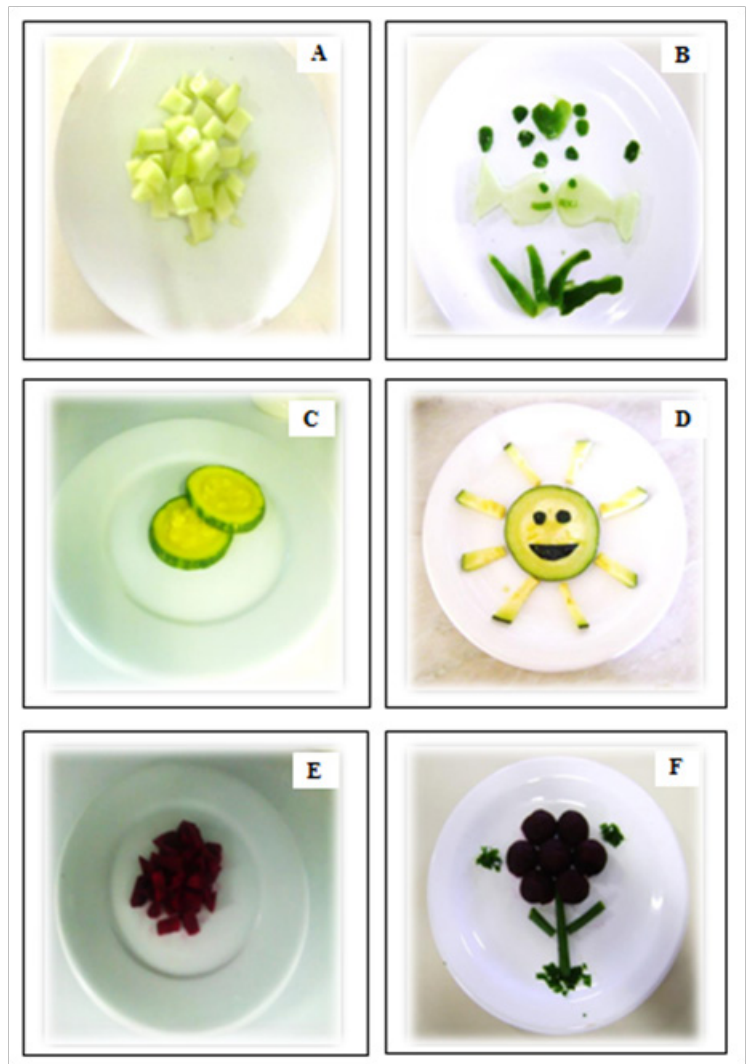

Figure 4 Use of the gastronomic techniques in vegetables. A) Chayote cubes; B) Fishes made with chayote; C) Zucchini slices; D) Sun made with zucchini; E) Beet; F) Flower made with beet and parsley.

\section{Discussion}

The fruits and vegetables consumption was not usual between most of evaluated children. The low consumption of fruits and vegetables was also identified in the Household Budget Survey in 2008/2009, in which these foods were mentioned as part of the meal only by $25 \%$ of children, ${ }^{1}$ may indicate that their intake is lower than the recommended daily amount, 400 to $500 \mathrm{~g}$ per day, according to World Health Organization. ${ }^{6}$ Costa et al., ${ }^{2}$ found that the average consumption of fruits and vegetables was 1.5 times per day, and that $26.6 \%$ of students did not consume these foods even once a day. Although children are aware of the importance and necessity to include fruits and vegetables in diet, Monis \& Ferratone $^{13}$ assessing schoolchildren aged 7 to 11 years, found that $41.5 \%$ of them do not consume vegetables, while $12.7 \%$ reported not enjoy fruits. According to dates from Brazilian Institute of Geography and Statistics, the Alto Paranaíba region is characterized by high agricultural production, noting that the city of Rio Paranaíba, Minas Gerais State, grows carrots, potatoes, and pumpkin on a large scale. In 2012 were harvested in this region about 75 tons of passion fruit, 120 of guava, and 325 of banana. ${ }^{14}$ Despite of children in this study live in a municipality with greater access to healthy foods, this fact has not been sufficient to them included in their eating habits, emphasizing the importance of developing actions to encourage the consumption of fruits and vegetables.

The gastronomic techniques were efficient to increase the grades on vegetables evaluation by the children. However, the grades attributed for fruit, decreased after use of gastronomic techniques, suggesting that this fact resulted from the change in the presentation form of these foods are showed during the frequent use by children. Farias \& Ravazzani ${ }^{15}$ evaluated the acceptability test in children ages 1 to 6years old, found that fruits and vegetables offered in different ways was accepted by $89.5 \%$ of children when compared to their acceptance using their usual consumption. Zampolo ${ }^{16}$ highlights that are required studies to prove that the gastronomy has an influence on the fruits and vegetables acceptance among overweight children, since such a technique has the power to make it more attractive.

Research conducted in hospitals that evaluated the application of this technique in the preparation of diets served to patients concluded that the use of gastronomic techniques improved the visual aspects of the foods served, and consequently the acceptance of meals. ${ }^{17-20}$ According to Souza \& Nakasato ${ }^{20}$ a meal becomes attractive and well accepted not only by its composition but also by their appearance and esthetics. Messias et al. ${ }^{19}$ found that the improvement in the food appearance tends to increase their acceptance, as well as the satisfaction of those who are consuming food. It's important to associate knowledge of nutrition to gastronomic practices, to promote and restore health and encourage food consumption, in addition to providing pleasure and well-being through different forms of meals presentation, increasing their acceptance..$^{17,19,20}$ Although they were observed the association in some grades is might consider that age, gender and food consumption may influence the acceptability, and the gastronomy cannot be indicated as the sole or primary factor impacting on food acceptance. In the study realized by Büyükkaragöz et al., ${ }^{21}$ the age and education were related to the functional foods consumption.

Children when they are in a more advanced age become more aware of the characteristics and quality of products that are consumed by them, been heavily influenced by the media and colleagues, they have as a main characteristic be vulnerable to fashion behaviors. ${ }^{22,23}$ Another important factor for the results obtained in this study, is the gastronomy cannot influence significantly fruits and vegetables acceptance among children because of the age studied. According to 
Mintem et al., ${ }^{24}$ in these ages children have probably formed opinions with the ability to decide about their habits and food preferences, so other factors may have no impact.

Borges et al., ${ }^{25}$ reported that the family has great influence on the formation of eating habits and children's lifestyle. Thus, the family influence should be used to establish healthy eating habits among children, avoiding the rise of risk factors for chronic diseases development in childhood. The family environment is one of the determinants of food acceptance among children, due their choices are influenced by their parents habits, making them responsible for offering the fruits and vegetables that usually have a low acceptance. Therefore, they should use this influence to promote healthy eating in their children, and consequently, educate healthier habits through knowing of new food. ${ }^{26}$ Besides family environment, the involvement of educators and health professionals in projects and intervention actions is necessary to promote nutrition education, and encourage the adoption of healthy lifestyle habits, considering that the school has a fundamental role in the formation of children and can improve the health of them. ${ }^{27}$ Promoting healthy eating habits, transmitting information through the use of different features such as leisure activities and gastronomic resources have shown positive results among children. Art can contribute in a significant way in the relevant concepts construction in health promotion. ${ }^{27-30}$ The preferences of children are developed not only by offering food, but also by how they are presented. Considering that, strategies such as the use of gastronomic resources combined with nutrition education may be more favorable, since they help in the healthy eating habits formation that can contribute to the growth and children development. ${ }^{24}$ As a limitation, the small number of children who participated in the study, suggesting that at least three evaluations should be performed with food before and after the use of gastronomic techniques and with an interval of at least one month.

\section{Conclusion}

The fruits and vegetables frequency consumption among children assessed was considered low, and the gastronomic techniques not statistically improved acceptance of fruits and vegetables. However, the grade attributed to vegetables after the use of gastronomic techniques was higher. Thereby, are required more studies which are capable to demonstrate the importance of gastronomic techniques, nutrition education strategies to promote an increase of fruits and vegetables consumption by children.

\section{Acknowledgements}

To the students and others involved in the study.

\section{Conflict of interest}

The authors point out that there is no conflict of interest in the preparation of the manuscript.

\section{References}

1. Pesquisa de Orçamentos Familiares 2008-2009: análise do consumo alimentar pessoal no. Brasil: Instituto Brasileiro de Geografia e Estatística-IBGE; 2010.

2. Costa LCF, Vasconcelos FAG, Corso ACT. Fatores associados ao consumo adequado de frutas e hortaliças em escolares de Santa Catarina, Brasil. Cad Saúde Pública. 2012;28(6):1133-1142.

3. Enes CC, Slater B. Obesidade na adolescência e seus principais fatores determinantes. Rev Bras Epidemiol. 2010;13(1):163-171.
4. Marcial JM, Altieri PI, Soto-Salgado M. Obesity in the development of premature coronary artery disease. Obesity: Open Access. 2016;2(1):1-4.

5. Brasil, Ministério da Saúde. Coordenação Geral da Política de Alimentação e Nutrição: Análise dos Registros do Consumo Alimentar, Boletim SISVAN. 2009:10.

6. World Health Organization (WHO). Diet, nutrition e the prevention of chronic diseases. Switzerland; 2003. 916 p.

7. Oliveira SPS, Tabai KC, Silva MSC, et al. Promoção do consumo de frutas, verduras e hortaliças em Unidades de Educação Infantil: diagnóstico inicial. Rio de Janeiro: Embrapa Agroindústria de Alimentos. 2008.

8. Sloan D. Gastronomia, restaurantes e comportamento do consumidor. São Paulo: Manole; 2005.

9. Franco A. De caçador a goumert:uma história da gastronomia. 5th ed. São Paulo: Senac; 2010.

10. Centro Colaborador em Alimentação e Nutrição Escolar - CECANE. Manual para aplicação dos testes de aceitabilidade no Programa Nacional de Alimentação Escolar - PNAE. São Paulo: Unifesp; 2010.

11. Lucia SMD, Minin VPR, Carneiro JDS. Análise sensorial de alimentos In: Minin VPR, editor. Análise sensorial: estudos com consumidores. Viçosa-MG: Editora UFV; 2013. p. 13-48.

12. Brasil, Agência Nacional de Vigilância Sanitária - ANVISA. Resolução da Diretoria Colegiada, no 216, de 15 de setembro de 2004. Dispõe sobre o Regulamento Técnico de Boas Práticas para Serviços de Alimentação. Diário Oficial da União. 2004.

13. Monis LVP, Ferratone VA. Investigação sobre escolhas alimentares de escolares do Município de Piracicaba. Saúde Rev. 2006;8:17-21.

14. Brasil, Instituto Brasileiro de Geografia e Estatística - IBGE. Cidades. Minas Gerais. Rio Paranaíba. Lavoura permanente. 2012.

15. Farias AM, Ravazzani EDA. Avaliação do consumo de legume e verdura em pré-escolares de um a seis anos de um Centro de Educação Infantil (CEI) do município de Pinhais-PR. Cad Escolas Saúde. 2012;5:90-101.

16. Zampolo AH. Importância da apresentação das refeições na alimentação infantil. 2007.

17. Bezerra AC. Gastronomia na prescrição de dietas hospitalares e as influências geradas pela indústria hoteleira. Brasíl: Universidade de Brasília; 2003.

18. Lages PC, Ribeiro RC, Soares LS. A gastronomia como proposta de qualificação dietética das refeições hospitalares pastosas: análise, intervenção e avaliação. Alim Nutr. 2013;24(1):93-99.

19. Messias GM, Presta FMP, Souza MVM. Benefícios da gastronomia hospitalar na alimentação do paciente idoso. Rev Eletrônica Novo Enfoque. 2011;12(12):23-31.

20. Souza MD, Nakasato M. A gastronomia hospitalar auxiliando na redução dos índices de desnutrição entre pacientes hospitalizados. O Mundo da Saúde. 2011;35(2):208-214.

21. Büyükkaragöz A, Bas M, Sağlam D, et al. Consumers' awareness, acceptance and attitudes towards functional foods in Turkey. Int J Consum Stud. 2014;38:628-635.

22. Fiates GMR, Amboni RDMC, Teixeira E. Marketing, hábitos alimentares e estado nutricional:aspectos polêmicos quando o temaé o consumidor infantil. Alim Nutr. 2006;17(1):105-112.

23. Juchen ST. Sensibilização de adolescentes para uma alimentação saudável. 2014.

24. Mintem GC, Victora CG, Lima RC. Fatores associados ao conhecimento e às preferências alimentares em crianças de 3 a 9 anos, na cidade de Pelotas, Brasil. J Health Biol Sci. 2013;1(1):27-38. 
25. Borges CF, Busnello FM, Pellanda LC. Identificação de fatores de risco cardiovascular em pais/cuidadores de crianças cardiopatas. Arq Bras Cardiol. 2012;99(4):936-943.

26. Rossi A, Moreira EAM, Rauen MS. Determinantes do comportamento alimentar: uma revisão com enfoque na família. Rev Nutr. 2008;21(6):739-748

27. Brito AKA, Silva FIC, França NM. Programas de intervenção nas escolas brasileiras: uma contribuição da escola para a educação em saúde. Saúde em Debate. 2012;36:624-632.
28. Lima DB, Simões TM, Lucia FD, et al. Crescendo com saúde e nutrição: aplicação do lúdico na educação nutricional. Em Extensão. 2009;8(2):59-67.

29. Magalhães CR. O jogo como pretexto educativo:educar e educar-se em curso de formação em saúde. Interface. 2007;11(23):647-654.

30. Toassa EC, Leal GVS, Wen CL, et al. Atividades lúdicas na orientação nutricional de adolescentes do Projeto Jovem Doutor. Nutrire: Rev Soc Bras Alim Nutr. 2010;35(3):17-27. 